\title{
Britain establishes Academy of Medical Sciences
}

Long-standing efforts to create a single professional organization in Britain dedicated to bringing together the basic and clinical biomedical sciences and raising their joint public profile, have finally come to fruition with an agreement to set up an Academy of Medical Sciences.

The creation of the academy was announced in London last month. The move follows two years of detailed preparatory work by a coordinating committee bringing together representatives of the Royal Society, the various royal medical colleges and university medical schools. Accommodation close to the premises of the Royal Society has been provided with financial support from the Wellcome Trust.

The Acadamy's activities will include raising public awareness of the importance of the biomedical sciences and advising the government on political issues concerning this discipline. "Medical science is an area which currently needs this type of high profile and we warmly welcome this new initiative," says Sandy Macara, the secretary of the British Medical Association.

Sir Leslie Turnberg, former president of the Royal College of Physicians and a member of the new Academy's coordinat- ing committee, says "this has been a gleam in the eye of the academic medical community, and the medical profession at large, for many years. But it has never before got to this point."

According to Turnberg, the interests of the association will range from the impact of modern biotechnology and the microchip on medicine to the ethics of cloning. "There doesn't seem to be a shortage of topics," he says, adding that it will also have "more than a passing interest in the problems of academic clinical medicine, as outlined in the Richards report published last year," (Nature Med. 3, 821; 1997).

Earlier efforts to create a single, umbrella organization for the medical sciences, such as one spearheaded by the Royal Society of Medicine, appear to have foundered because of over zealous concern about traditional 'turf' issues by the royal medical colleges, who were apparently reluctant to cede their influence over research related issues.

In addition to a desire to strengthen links between basic research and clinical practice, the new initiative is said to have stemmed partly from pressure on the medical colleges to concentrate more on meeting professional needs of their members and partly from the desire of the pre- vious president of the Royal Society, the mathematician Sir Michael Atiyah, to see the biomedical sciences given a higher public profile.

Indeed, Atiyah has argued that the Royal Society's active support for the new body repays the substantial backing that the society itself received from prominent members of the medical profession when it was established in the middle of the seventeenth century.

"We are going to do for the medical sciences what the Royal Society does for the natural sciences and the Royal Academy of Engineering does for the engineering sciences," says Peter Lachmann, professor of immunology at the University of Cambridge and biological secretary of the Royal Society. Lachmann will act as the new academy's interim president until its officers are formally elected later this year.

Lachmann points out that some of the Academy's activities will mirror those of the US Institute of Medicine (IOM), although the British academy will have a much smaller staff. And, unlike the IOM which is formally linked to the National Academy of Sciences, "we do start as an independent academy," he says.

DAVID DICKSON, LONDON

\section{IOM panel has begun NIH spending investigation}

An Institute of Medicine (IOM) inquiry into the policies and processes used by the US National Institutes of Health (NIH) to determine funding allocations for biomedical research began last month. The investigation was requested by Congress last year and is the first IOM study to evaluate NIH budget distribution since 1984 .

The study_said to be costing $\$ 338,000$ - has been "fast-tracked" and the panel's report is expected by July $1^{\text {st }}$. The recommendations will be used by Senator Bill Frist (R-Tenn.), chairman of the Senate Labor and Human Resources Committee's Public Health and Safety subcommittee, to draft the $\mathrm{NIH}$ reauthorization bill later this year.

In addition to assessing what criteria the NIH uses to distribute its $\$ 13.65$ billion budget for disease research, Congress has asked the panel to examine "the mechanisms for public

input into the priority-setting process." One consensus that seemed to emerge from the panel's first meeting on March $6^{\text {th }}$, at which NIH directors and congressional representatives spoke, was that the NIH should pay more attention to public opinion. Disease group advocates will be given

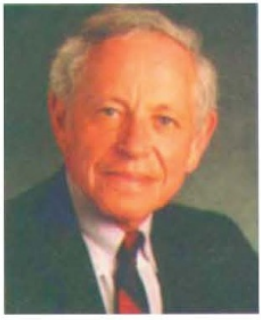

Leon Rosenberg

health services researchwhether this area warrants such a slice of the pie or notHyman said that this "entrenches self-interested constituencies" and "deforms" science.

Statements made in praise of the system currently used by $\mathrm{NIH}$, led to comments that the panel's work is the opportunity to rein-

force this message when they address the panel at a public forum on April $3^{\text {rd }}$ in

IMAGE Washington D.C. UNAVAILABLE The panel has also been asked to evaluate the "impact FOR COPYRIGHT of statutory directives on research funding decisions." National Institute of Mental Health (NIMH) director, Steven Hyman, remarked on this at the March meeting. In discussing the congressional mandate to devote 15 percent of the NIMH budget to merely window-dressing and that it endorses NIH's methods from the outset. However, panel chairman Leon Rosenberg, a Princeton University professor of molecular biology and former president of Pharmaceutical Research at Bristol-Myers Squibb, warns against prejudging the outcome of the investigation. Rosenberg reiterated the panel's objective to Nature Medicine, "the question we have been asked is, as we end this century and period of very successful NIH, how can we make it better?"

Karen Birmingham, New YorK 